\title{
Growth Pattern, Fruit Body Characteristics and Period of Spawning on Yield and Yield Attributing Parameters of Indian Oyster Mushroom, Pleurotus pulmonarius
}

\author{
Pagoti Hemalatha", K.B. Mohapatra", N. Nayak and N. Chinara \\ Department of Plant Pathology, College of Agriculture, Orissa University of Agriculture and \\ Technology, Bhubaneswar-751003, India \\ *Corresponding author
}

\begin{tabular}{|l|}
\hline K e y w o r d s \\
$\begin{array}{l}\text { Growth pattern, Fruit } \\
\text { body, Spawning, Yield, } \\
\text { Oyster mushroom, } \\
\text { Pleurotus pulmonarius }\end{array}$ \\
\hline Article Info \\
\hline $\begin{array}{l}\text { Accepted: } \\
\text { 26 September } 2018 \\
\text { Available Online: } \\
\text { 10 October } 2018\end{array}$ \\
\hline
\end{tabular}

\section{Introduction}

Pleurotus mushroom, generally referred to as 'Oyster mushroom or Dhingri' in India is relatively new to the mushroom industry but has gained popularity at a tremendous pace

\section{A B S T R A C T}

Pleurotus mushroom, generally referred to as 'Oyster mushroom or Dhingri' in India is relatively new to the mushroom industry. In India, Odisha is a leading state in terms of oyster mushroom production. The condition in most of agro-climatic situation in Odisha are suitable for growing oyster mushroom from month of July to February comprising of the rainy and winter season. Pleurotus pulmonarius is a potential protein source especially in developing countries, besides having minerals and vitamins. Besides its edibility it has also got pharmaceutical properties. Hence, Pleurotus pulmonarius could well be incorporated in to the mushroom farming system during winter season besides the ruling species, as this species was not in cultivation earlier. Studies on growth pattern and fruit body characteristics revealed that the mycelium $P$. pulmonarius was dense strandy on PDA medium with pale white colony colour. The pileus diameter, stipe length and stipe thickness varied between 5.2-10.0, 2.5-5.5 and 0.9-2.3cm respectively. The margin of the fruit body was found to be wavy with pale white pileus colour. Among the nine substrates evaluated for their yield potential, superiority of paddy straw was established in terms of realization of biological efficiency $(99.30 \%)$. Sugarcane bagasse, rice bran and saw dust were found inferior with biological efficiency of $61.07,70.20$ and $77.40 \%$ respectively. The biological efficiency varied within $61.07 \%$ on sugarcane bagasse to $99.30 \%$ on paddy straw. The biological efficiency was numerically highest $(100.17 \%)$ on the $1^{\text {st }}$ January, 2016 spawning which was statistically equal to $1^{\text {st }}$ and $16^{\text {th }}$ December, 2015 spawning (99.15 and 99.87\%) among the eight spawning dates evaluated during the winter season at 15 days interval each. The results thus revealed that December and January spawning was appropriate in realizing superior yields out of $P$. pulmonarius.

and today it is cultivated in about 25 countries of far-East Asia, Europe and America. It is the third largest cultivated mushroom in the world and its annual production is around 8.75, 000 tonnes (Chang and Miles, 2004). China alone contributes $88 \%$ of the world production. The 
other major producing countries are South Korea, Japan, Italy, Taiwan, Thailand and Philippines.

At present India produces only small quantities $(10,000$ tonnes) of oyster mushroom in Orissa, Karnataka, Maharashtra, Andhra Pradesh, Tamil Nadu, Bihar, Madhya Pradesh, Chhattisgarh, Jharkhand, West Bengal and in the North-Eastern states of Meghalaya, Manipur, Mizoram, Tripura and Assam.

In India, Odisha is a leading state in terms of oyster mushroom production and contributing to about $40 \%$ of the total mushroom production of the state. The condition in most of agro-climatic situation in Odisha are suitable for growing oyster mushroom from month of July to February comprising of the rainy and winter season. However, people of Odisha prefer growing oyster mushroom during winter season i.e. from November to February when productivity of paddy straw mushroom declines owing to low temperature. Pleurotus florida and Pleurotus sajor-caju are the preferred species in the state. Besides these two species, $P$. eous is also gaining popularity both in the coastal as well as inland situations.

Pleurotus pulmonarius is a potential protein source especially in developing countries, besides having minerals and vitamins. Besides its edibility it has also got pharmaceutical properties. Hence, Pleurotus pulmonarius could well be incorporated in to the mushroom farming system during winter season besides the ruling species, as this species was not in cultivation earlier. Hence the effective of various conventional as well as nonconventional substrates and various growing techniques need to be standardized for the purpose of wide spread cultivation. Therefore, an attempt has been made to investigate the suitable package of practices for Pleurotus pulmonarius cultivation to be followed by the growers to achieve good yield.

\section{Materials and Methods}

Test fungus: Different studies were undertaken during the course of investigation by taking only one species of oyster mushroom fungus, Pleurotus pulmonarius, the test fungus was procured from the Centre of Tropical Mushroom Research and Training (CTMRT). Department of Plant Pathology. Collage of Agriculture, Orissa University of Agriculture and Technology, Bhubaneswar.

Maintenance of culture: The pure culture of the fungus was maintained on potato dextrose agar (PDA) Slant throughout the period of investigation. The fungus was sub cultured at an interval of two months and stored at $25 \pm 1{ }^{0} \mathrm{C}$. Fifteen days old pure mycelia cultures of test fungus were used in various studies.

\section{Preparation of substrate}

A single bag $(80 \mathrm{~cm} \times 40 \mathrm{~cm})$ needed three bundles of paddy straw which weighed approximately $1500 \mathrm{~g}$. The hand threshed, uncrumpled straw devoid of leafy materials was preferred. The straw was chopped into 1.5-2" size through a chaff cutter, packed in gunny bags and was soaked in water containing $125 \mathrm{ml}$ of formalin and $7.5 \mathrm{~g}$ of Bavistin per 90 litres of water for a period of six hours. Straw was pressed and covered with a polythene sheet. The straw was taken out and excess water was drained by spreading the straw on a clean cemented floor. Prior to raising bags, the moisture content of substrate was maintained at $65 \%$ which was confirmed through palm test.

\section{Spawning of the substrate}

Freshly prepared grain spawn (20-30 days old) was procured for spawning. The spawning was done in a pre-fumigated room (48hours with $2 \%$ formalin). The spawn requirement 
was $10 \%$ of the dry weight of substrate $(150 \mathrm{~g}$ of spawn per bag having $1.5 \mathrm{~kg}$ of dry substrate). The spawn was removed from the bottle with a clean and sterilized iron rod and divided into four parts. Each part of spawn as well as the supplement were put inside the polythene bag of $80 \mathrm{~cm} \times 40 \mathrm{~cm}$ size on each layer of substrate having 5-6" thickness close to the edge. Four layers of substrate were seeded with spawn along with supplement and the upper end of the bag was tied up. Ten to 15 small holes $(0.5-1.0 \mathrm{~cm}$ dia) were made on all sides of the bag including two to four holes in the bottom to leach out excess water and to facilitate gas exchange.

\section{Yield and biological efficiency}

The biological efficiency was calculated by the following formula

BE

Fresh weight of mushroom harvested

Dry weight of the substrate $\times 100$

\section{Morphological characterization Pleurotus pulmonarius}

of

Morphological characterization of Pleurotus pulmonarius was done in order to ascertain its identity. For this purpose, the test species was grown in bag method as standard protocol. After mycelial run was over, the bags were uncovered and put on the shelves in the mushroom growing room. Watering of bags was done as and when required. Fruit bodies were harvested from the first flush at the appropriate time. A random of 10 fruit bodies were collected and brought to the laboratory of the pileus, stipe length, stipe thickness, margin and texture of fruit body were recorded.

Influence of weather parameters on biological efficiency of Pleurotus pulmonarius: In an attempt to find out the appropriate time of cultivation of Pleurotus pulmonarius bags were raised at 15 days interval from November $1^{\text {st }}$ to February $28^{\text {th }}, 2015-16$ covering the winter season. Bags were prepared following the standard protocol as described earlier. However, the cultivation was subjected to ambient conditions in the mushroom growing room to ascertain the appropriate time of cultivation. Triplicates were maintained for each treatment in Randomized Block Design. Observation on time taken for spawn run, first harvest, average weight of fruiting body and mushroom yield were recorded.

\section{Results and Discussion}

\section{Growth pattern and fruit body characteristics of Pleurotus pulmonarius}

Among all the cultivated mushrooms, Pleurotus is appreciated for its culinary properties and broad adaptability under varied agro-climatic conditions. Simple cultivation technique, highest productivity, choice of species/variety, ability to degrade a large number of substrates and after all, longer shelf life has made this mushroom the preferred one among the tropics and sub-tropical ones.

The test species was grown aseptically in the petriplates containing potato dextrose agar medium for observation on the growth pattern. The data on pileus size, stipe length, stipe thickness, along with few morphological characters are presented in Table 1.

The observation on morphological characteristics of the test species raised in the month of December indicated that the mycelium of Pleurotus pulmonarius was compact and dense on PDA medium with pale with cottony colour. The pileus diameter, stipe length and stipe thickness varied between 5.2$10.0,2.5-5.5$ and $0.9-2.3 \mathrm{~cm}$ respectively. In all the 10 fruit bodies observed, the margin 
was found to be wavy with pale white pileus colour.

The study and growth pattern and fruit body characteristics of Pleurotus palmonarius raised during the month of December indicated that on the potato dextrose agar medium, the growth pattern of the species was dense strandy in behavior. Further, the colour of the fruit bodies was pale white at large. Margins of the fruit bodies were entire when young, wavy at harvest. The pileus diameter, stipe length and stipe thickness varied between 5.2 to $10.0,2.5$ to 5.5 and 0.9 to $2.3 \mathrm{~cm}$ respectively. Singh et al., (2010) established the fact that among all the edible mushrooms, wide variation in shape, color, margins of the fruit body and growth pattern on nutrient media existed in Pleurotus. Shukla and Jaitly
(2011) characterized different species of Pleurotus morphologically which was conformity to the findings of this investigation.

\section{Effect of period of spawning on biological efficiency of Pleurotus pulmonarius}

Traditionally, Pleurotus spp. is growing during winter months (November - February) in the state of Odisha. However in an attempt to find out the influence of spawning period on yield and associated parameters, a trail was formulated by growing this newly introduced species from November - February at 15 days interval in the ambient situation. The data recorded on yield and yield attributing parameters were analysed and are presented in Table 2.

Table.1 Growth pattern and fruit body characteristics of Pleurotus pulmonarius

\begin{tabular}{|c|c|c|c|c|c|c|c|c|}
\hline \multirow[t]{2}{*}{$\begin{array}{l}\text { Sl. } \\
\text { No. }\end{array}$} & \multicolumn{3}{|c|}{ Growth pattern on PDA } & \multicolumn{5}{|c|}{$\begin{array}{l}\text { Characteristics of fruit bodies on paddy straw } \\
\text { substrate }\end{array}$} \\
\hline & $\begin{array}{l}\text { Mycelia } \\
\text { density }\end{array}$ & $\begin{array}{l}\text { Type of } \\
\text { growth }\end{array}$ & $\begin{array}{l}\text { Colony } \\
\text { colour }\end{array}$ & $\begin{array}{l}\text { Pileus } \\
\text { size } \\
(\mathrm{cm})\end{array}$ & $\begin{array}{l}\text { Stipe } \\
\text { length } \\
(\mathrm{cm})\end{array}$ & $\begin{array}{c}\text { Stipe } \\
\text { thickness } \\
\text { (cm) }\end{array}$ & colour & Margin \\
\hline 1 & Dense & Dense strandy & Pale white & 7.4 & 4.0 & 0.9 & Pale white & Wavy \\
\hline 2 & Dense & Dense strandy & Pale white & 8.5 & 4.0 & 1.0 & Pale white & Wavy \\
\hline 3 & Dense & Dense strandy & Pale white & 6.5 & 3.0 & 1.2 & Pale white & Wavy \\
\hline 4 & Dense & Dense strandy & Pale white & 6.7 & 3.8 & 1.0 & Pale white & Wavy \\
\hline 5 & Dense & Dense strandy & Pale white & 16.0 & 4.2 & 2.1 & Pale white & Wavy \\
\hline 6 & Dense & Dense strandy & Pale white & 6.3 & 4.3 & 1.2 & Pale white & Wavy \\
\hline 7 & Dense & Dense strandy & Pale white & 5.2 & 5.5 & 2.3 & Pale white & Wavy \\
\hline 8 & Dense & Dense strandy & Pale white & 6.5 & 2.5 & 0.9 & Pale white & Wavy \\
\hline 9 & Dense & Dense strandy & Pale white & 7.8 & 3.4 & 1.4 & Pale white & Wavy \\
\hline 10 & Dense & Dense strandy & Pale white & 6.8 & 4.2 & 1.2 & Pale white & Wavy \\
\hline Mean & - & - & - & 7.17 & 3.89 & 1.32 & - & - \\
\hline
\end{tabular}


Table.2 Effect of period of spawning on biological efficiency of Pleurotus pulmonarius

\begin{tabular}{|c|l|c|c|c|c|}
$\begin{array}{c}\text { Sl. } \\
\text { No. }\end{array}$ & \multicolumn{1}{|c|}{$\begin{array}{c}\text { Treatment } \\
\text { (Date of Spawning) }\end{array}$} & $\begin{array}{c}\text { Days to } \\
\text { spawn run }\end{array}$ & $\begin{array}{c}\text { Days to } \\
\text { first } \\
\text { harvest }\end{array}$ & $\begin{array}{c}\text { Average weight } \\
\text { of fruit bodies } \\
(\mathbf{g})\end{array}$ & $\begin{array}{c}\text { Biological } \\
\text { efficiency } \\
(\%)\end{array}$ \\
\hline $\mathbf{1}$ & 1.11 .2015 & 20.00 & 27.33 & 7.90 & 88.93 \\
\hline $\mathbf{2}$ & 16.11 .2015 & 20.67 & 27.00 & 8.04 & 88.00 \\
\hline $\mathbf{3}$ & 1.12 .2015 & 17.00 & 23.33 & 10.67 & 99.15 \\
\hline $\mathbf{4}$ & 16.12 .2015 & 15.67 & 22.67 & 10.64 & 99.87 \\
\hline $\mathbf{5}$ & 1.01 .2016 & 16.00 & 22.67 & 10.42 & 100.17 \\
\hline $\mathbf{6}$ & 16.01 .2016 & 16.67 & 24.67 & 8.53 & 80.43 \\
\hline $\mathbf{7}$ & 1.02 .2016 & 17.00 & 25.67 & 8.17 & 80.33 \\
\hline $\mathbf{8}$ & $\mathbf{1 6 . 0 2 . 2 0 1 6}$ & 20.67 & 29.00 & 7.67 & 77.37 \\
\hline & CD $(0.05)$ & 1.72 & 0.98 & 0.98 & 3.72 \\
\hline & CV $(\%)$ & 5.48 & 2.22 & 6.18 & 2.38 \\
\hline
\end{tabular}
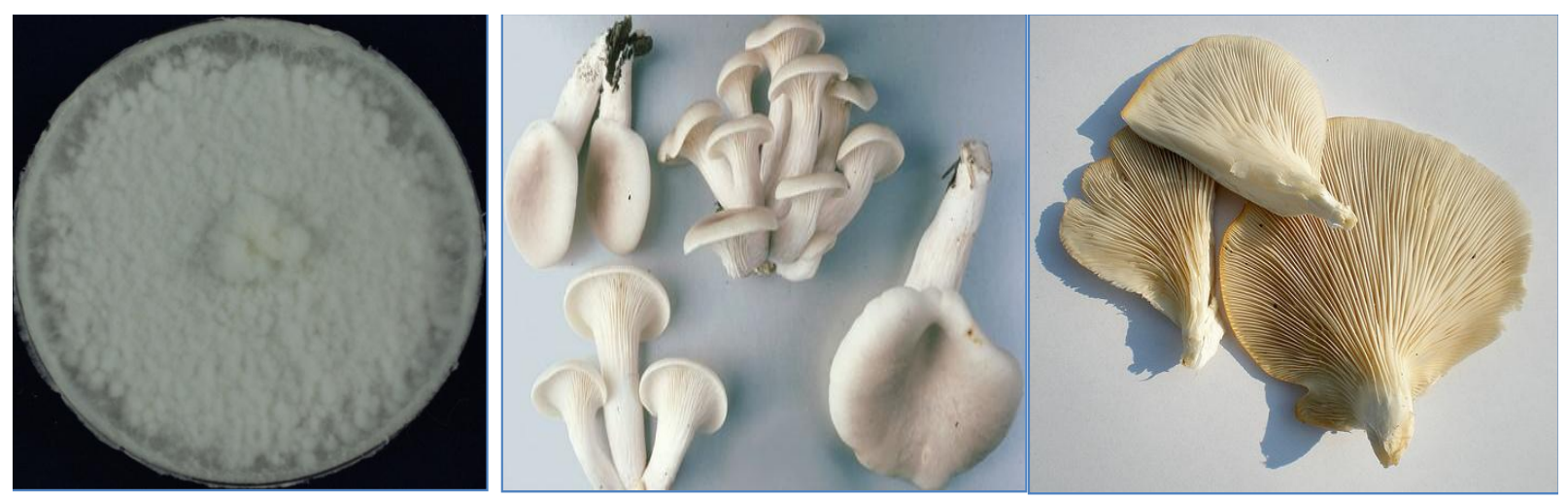

Fig: Culture of Pleurotus pulmonarius Fig: Detached fruit bodies of $P$. pulmonarius Fig :Fruit bodies

Analysis of data showed significant difference among the eight dates of spawning. It was observed that spawning from $1^{\text {st }}$ December, 2015 till $1^{\text {st }}$ February, 2016 (fire date) were it par in respect of days of spawn were in the range of 15.67-17.00 days. The incubation period was lengthened as the spawning period was either preponed or postponed. The same trend was also noticed in respect of days to first harvest (crop duration). Average weight of fruit bodies were recorded maximum on its $1^{\text {st }}$ December, 2015 spawning which as at par with spawning at $16^{\text {th }}$ December, 2015 and $1^{\text {st }}$ January, 2016. The biological efficiency was numerically highest $(150.17 \%)$ on $1^{\text {st }}$ January, 2016 spawning which was statistically equal to $1^{\text {st }}$ and $16^{\text {th }}$ December, 2015 spawning (99.15 and 99.86\%). The results revealed that December and January spawning were appropriate in realizing superior yields out of Pleurotus pulmonarius.

Pleurotus mushroom, being a sub-tropical mushroom, comes up well in winter season in the East and South-Eastern coastal plain zone of Odisha. In order to find out the appropriate time of spawning, eight dates of spawning starting from $1^{\text {st }}$ November, 2015 to $16^{\mathrm{th}}$ February, 2016 were evaluated for their yield potential. Analysis of data showed significant difference among the eight dates of spawning in respect of yield and associated parameters. 
The biological efficiency was numerically highest $(100.17 \%)$ in $1^{\text {st }}$ January, 2016 spawning which was statistically equal to $1^{\text {st }}$ and $16^{\text {th }}$ December, 2015 spawning $(99.15$ and $99.87 \%$ ). It was thus ascertained that for coastal situation of the state, December and January spawning were appropriate in realization of higher yields. Unlike other cultivated mushrooms, species of Pleurotus exhibit much diversity in their adaptability to varying agro-climatic conditions. Various workers have shown to recover good yields out of oyster mushroom raised during rainy/winter seasons at a temperature of 17.2$35^{\circ} \mathrm{C}$ and relative humidity 70-90\% (Bano and Rajarathnam, 1978 and Sanger et al., 2006).

Studies on growth pattern and fruit body characteristics revealed that the mycelium $P$. pulmonarius was dense strandy on PDA medium with pale white colony colour. The pileus diameter, stipe length and stipe thickness varied between 5.2-10.0, 2.5-5.5 and $0.9-2.3 \mathrm{~cm}$ respectively. The margin of the fruit body was found to be wavy with pale white pileus colour.

The biological efficiency was numerically highest $(100.17 \%)$ on the $1^{\text {st }}$ January, 2016 spawning which was statistically equal to $1^{\text {st }}$ and $16^{\text {th }}$ December, 2015 spawning $(99.15$ and $99.87 \%$ ) among the eight spawning dates evaluated during the winter season at 15 days interval each. The results thus revealed that December and January spawning were appropriate in realizing superior yields out of P. pulmonarius.

\section{References}

Bano Z, Rajarathnam S and Nagarajan N. 1978. Some aspects on the cultivation of Pleurotus flabellatus in India. Mushroom Science, 10(2): 597-607.

Chang S T and Miles PG. 2004. VolvariellaA high temperature cultivated mushroom. In: Mushroom cultivation, Nutritional value, Medical effect and Environmental impact. (Eds) Chang S.T. and Miles, P.G. pp 277-304.

Sanger R B S, Thakur M P and Shulka C S. 2006. Recent advances in production technology of oyster mushroom, (In) emerging areas in mushroom diversity, production and post-harvest developments (Thakur ed.), pp.89-99.

Shubhra Shukla and A KJaitly. 2011. Morphological and biochemical characterization of different oyster mushroom (Pleurotus spp.). J.phytol. 3(8): 18-20.

Singh A, Shahid M, Mishra R and Srivastava M. 2010. Quality attributes of different species of mushroom. Indian J. Agric. Biochem. 23(2): 141-142.

\section{How to cite this article:}

Pagoti Hemalatha, K.B. Mohapatra, N. Nayak and Chinara, N. 2018. Growth Pattern, Fruit Body Characteristics and Period of Spawning on Yield and Yield Attributing Parameters of Indian Oyster Mushroom, Pleurotus pulmonarius. Int.J.Curr.Microbiol.App.Sci. 7(10): 36323637. doi: https://doi.org/10.20546/ijcmas.2018.710.420 